\title{
Influence of Substrate Humidity on Desiccation Resistance Capacity in Subulina octona (Mollusca, Subulinidae)
}

\author{
Roberto Júnio Pedroso Dias ${ }^{1}$, Elisabeth Cristina de Almeida Bessa ${ }^{2,4}$ and Sthefane \\ D’Ávila ${ }^{3,4^{*}}$ \\ ${ }^{1}$ Universidade Federal de Juiz de Fora; Programa de Pós-graduação em Ciências Biológicas - Comportamento e \\ Biologia Animal; Bolsista CAPES; 36036-900; Juiz de Fora - MG - Brasil. ${ }^{2}$ Universidade Federal de Juiz de Fora; \\ Instituto de Ciências Biológicas; Departamento de Zoologia; 36036-330; Campus Universitário, Juiz de Fora - MG \\ - Brasil. ${ }^{3}$ Universidade Federal Rural do Rio de Janeiro; Curso de Pós-graduação em Ciências Veterinárias; \\ Bolsista CNPq - Seropédica - RJ - Brasil. ${ }^{4}$ Núcleo de Malacologia; Universidade Federal de Juiz de Fora; 36036- \\ 900; Juiz de Fora - MG - Brasil
}

\begin{abstract}
The aim of this study was to verify the influence of substrate humidity on desiccation resistance of Subulina octona, continuously exposed, for $48 \mathrm{~h}$, to the temperature of $35{ }^{\circ} \mathrm{C}$. Forty individuals conditioned in 2 plastic boxes, one box containing black earth humidified with $40 \mathrm{ml}$ water and the other one containing dry black earth were used. The retraction of cephalopodal mass inside the shell and the number of dead individuals was evaluated. Snails from dry and humid substrate boxes showed cephalopodal mass retraction of $9.9 \mathrm{~cm} \pm 2.88$ and $2.78 \mathrm{~cm} \pm 3.17$, respectively, after $12 \mathrm{~h}$ of exposure; $8.55 \mathrm{~cm} \pm 1.3$ and $6.33 \mathrm{~cm} \pm 2.91$, after $24 \mathrm{~h} ; 11.07 \mathrm{~cm} \pm 4.19$ and $7.27 \mathrm{~cm} \pm 2.7$, after $36 \mathrm{~h}, 9.12 \mathrm{~cm} \pm 2.15$ and $6.47 \mathrm{~cm} \pm 2.11$, after $48 \mathrm{~h}$. Every individual of dry substrate box died whereas every individual of humid substrate box survived. These results showed that substrate humidity was an influent factor regarding desiccation resistance in $S$. octona.
\end{abstract}

Key words: Land snail, desiccation, cephalopodal mass retraction, substrate, humidity

\section{INTRODUTION}

A conspicuous ecological characteristic of terrestrial pulmonate mollusks is an intense dependence of humidity, which is reflected on its behavior, activity period, habitat preference and procreation activity (Elwell and Ulmer, 1971; Dimitrieva, 1975; Pieri and Jurberg, 1981). This characteristic is shown by several physiological and behavioral adaptations exhibited by these animals. Such adaptations represent efficient solutions for the problems related to environmental conditions.
The substrate on which a pulmonate lives provides it humidity, food, protection, camouflage and oviposition sites and, therefore, it influences procreation, growth and survival on these animals. Under desiccation conditions, the substrate constitutes a source of humidity for mollusks rehydration (Cook, 2001). Subulina octona shows a close association with the substrate (Dutra, 1980; D'ávila et al., 2004). This influences on the growth and the procreation of these mollusks (D’ávila et al., 2004).

The aim of this study was to verify the influence of substrate humidity on desiccation resistance of

\footnotetext{
${ }^{*}$ Author for correspondence
} 
S. octona, continuously exposed for $48 \mathrm{~h}$, to the temperature of $35^{\circ} \mathrm{C}$.

\section{MATERIAL AND METHODS}

Forty individuals were obtained from the matrix of mollusk Laboratory of Biological Sciences PostGraduation Course (Animal Biology and Behavior) of Universidade Federal de Juiz de Fora, Minas Gerais, Brazil. The animals were conditioned in two plastic boxes $(12 \mathrm{~cm}$ diameter and $9 \mathrm{~cm}$ depth, 20 individuals/box). The first box contained black earth humidified with $40 \mathrm{ml}$ water and the other one contained dry black earth. Both boxes were kept in a chamber acclimatized to the temperature of $35{ }^{\circ} \mathrm{C}$ and $80 \%$ relative humidity, for $48 \mathrm{~h}$. Cephalopodal mass retraction inside the shell, perceptible due to its transparence, was measured through a pachymeter at intervals of 12 h. After $48 \mathrm{~h}$ of exposure, the number of dead individuals was verified. Statistical treatment of the data was by ANOVA analysis.

\section{RESULTS AND DISCUSSION}

Individuals from dry and humid substrate boxes showed cephalopodal mass retraction of $9.9 \mathrm{~cm} \pm$ 2.88 and $2.78 \mathrm{~cm} \pm 3.17$, respectively after $12 \mathrm{~h}$ of exposure; $8.55 \mathrm{~cm} \pm 1.3$ and $6.33 \mathrm{~cm} \pm 2.91$ after $24 \mathrm{~h} ; 11.07 \mathrm{~cm} \pm 4.19$ and $7.27 \mathrm{~cm} \pm 2.7$ after 36 $\mathrm{h}$; and $9.12 \mathrm{~cm} \pm 2.15$ and $6.47 \mathrm{~cm} \pm 2.11$ after 48 h. ANOVA analysis $(p<0.005)$ showed that the difference between these averages was significant. After $48 \mathrm{~h}$, every individual of dry substrate box died, whereas every individual of humid substrate box survived. Epiphragm formation was not observed.

The results showed the role of substrate humidity in mollusk survival during adverse conditions of temperature. Terrestrial gastropods loose water by the tegument and, in the same way, they rehydrate by the tegument, through the so-called rehydration by contact (Cook, 2001). In this context, the amount of water retained by substrate in which mollusks live influences the maintenance of homeostasis by these organisms. These animals are not able to absorb the humidity of saturated air (Cook, 2001), and because of this although relative humidity was kept in favorable conditions during the study, the animals kept in dry substrate died after $48 \mathrm{~h}$ of exposure.

Cephalopodal mass retraction is a generalized behavioral response among terrestrial mollusks during adverse conditions of temperature and humidity and it takes part in the series of biochemical, physiological, and behavioral changes that occurs with aestivation (Richardot, 1977a,b; Stiglingh and Van Eeden, 1977; Storey, 2002). Among the critical survival elements during aestivation period, there is the mollusk capacity of retaining water. Protected places selection, submersion in substrate, cephalopodal mass retraction inside the shell and immobilization corporeal water maintenance in levels that are compatible with mollusk survival. Submersion constitutes a behavioral response exhibited by several mollusk species during adverse conditions of humidity and temperature. Slugs resist to desiccation by submerging in the ground and by covering up their retracted bodies with mucus (Hyman, 1967; Wiktor, 1987). Individuals of species Derosceras caucasicum and Parmacella rutellum have their activity inhibited and use to submerge in the ground, to hide in the plants' basis or under lumps of soil, when relative humidity is under 18\% (Dimitrieva, 1975). Some species of genus Biomphalaria (Preston, 1910) submerge in the mud when habitat desiccation occurs (Pieri and Jurberg, 1981). This behavior, very frequent in $S$. octona even under favorable conditions, reduces desiccation risk since substrate provides the humidity that is necessary to mollusks survival and since it may work as an obstacle to corporal water evaporation. D`ávila et al. (2004) observed in $S$. octona, which were kept in boxes without substrate, an average cephalopodal mass retraction of $14.37 \mathrm{~cm}$ after $48 \mathrm{~h}$ of exposure to the temperature of $35^{\circ} \mathrm{C}$. The retraction observed was superior to the one verified in the current study for individuals kept in humid substrate $(6.47 \mathrm{~cm})$ and in dry substrate $(9.12 \mathrm{~cm})$, which reinforced the role of substrate as an obstacle to corporal water evaporation and as a source of water to mollusks rehydration.

The capacity of desiccation resistance in terrestrial mollusks may be correlated to the preferential habitat and to the species lifestyle (Arad, 1993; Emberton, 1994). According to Luchel and Deyrup-Olsen (2001), shell and epiphragm density, as well as the diameter of shell's aperture related to body size, may indicate a better or worse adaptation to dry habitats. S. octona rarely forms 
epiphragms (when they do so, epiphragm are constituted by thin and transparent pellicles) and it is frequently found in the substrate, most of the time submerged. This species is probably adapted to humid and shaded environments and is sensitive to light and heat exposure (Dutra, 1980; D`ávila et al., 2004).

Results in the current study demonstrated that substrate humidity was an influent factor on desiccation resistance of $S$. octona since humid substrate provided survival chances to mollusks.

\section{RESUMO}

O objetivo deste trabalho foi verificar a influência da umidade do substrato sobre a resistência à dessecação em indivíduos da espécie $S$. octona, submetidos a uma exposição contínua, por 48 horas, à temperatura de $35^{\circ} \mathrm{C}$. Foram utilizados 40 indivíduos, acondicionados em dois potes plásticos, um pote contendo terra vegetal ${ }^{\circledR}$ umedecida com $40 \mathrm{ml}$ de água e outro contendo terra vegetal seca, mantidos em câmara climatizada a $35 \pm 1{ }^{\circ} \mathrm{C}$. Foram verificados, a retração da massa cefalopodal no interior da concha e o número de indivíduos mortos. Os moluscos do pote com substrato seco e do pote com substrato úmido apresentaram retração da massa cefalopodal de $9,9 \mathrm{~cm} \pm 2,88$ e $2,78 \mathrm{~cm} \pm 3,17$ respectivamente, após 12 horas de exposição; $8,55 \mathrm{~cm} \pm 1,3$ e $6,33 \mathrm{~cm} \pm 2,91$, após 24 horas; $11,7 \mathrm{~cm} \pm 4,19$ e $7,27 \mathrm{~cm} \pm 2,7$, após 36 horas e $9,12 \mathrm{~cm} \pm 2,15$ e $6,47 \mathrm{~cm} \pm 2,11$, após 48 horas. Todos os indivíduos do pote com substrato seco morreram, enquanto todos os indivíduos do pote com substrato úmido sobreviveram. Esses resultados demonstram que a umidade do substrato é um fator que influencia a resistência à dessecação em S. octona.

\section{REFERENCES}

Arad, Z. (1993), Water relations and resistance to dessiccation in three israeli desert land snails, Eremina desertorum, Euchondrus desertorum and Euchondrus albulus. J. Arid Environm., 24, 387-395.

Cook, A. (2001), Behavioral ecology . In-The biology of terrestrial mollusks, ed. G.M. Barker, CABI Publishing, New Zeland, pp. 447-488.
D`ávila, S., Dias, R.J.P., Bessa, E.C.A. and Daemon, E. (2004), Resistência à dessecação em três espécies de moluscos terrestres: aspectos adaptativos e significado para o controle de helmintos. Rev. bras. Zoociências, 6 (1), 115-127.

Dimitrieva, E.F. (1975), The influence of temperature and moisture of the upper soil layer on the hatching intensity of the slug Deroceras reticulatum Muller. Malacol. Rev., 10, 32-45.

Dutra, A.V.C. (1980), Aspectos da biologia e da reprodução de Leptinaria unilamellata (Orbigny,1835) (Gastropoda, Subulinidae). Revta bras. Zool., 5 (4), 581-591.

Emberton, K.C. (1994), Morphology and aestivation behaviour in some madagascan acavid land snails. Biol. J. Linn. Soc., 53, 175-187.

Elwell, A.S. and Ulmer, M.J. (1971), Notes on the biology of Anguispira alternata (Stylommatophora: Endodontidae). Malacologia, 11 (1), 199-216.

Hyman, L.H. (1967), The invertebrates: Mollusca I. Vol. VI. Mc Graw Hill Book Company, New York.

Luchel, D.L. and Deyrup-Olsen, I. (2001), Body wall: Form and function. In $\neg$-The biology of terrestrial mollusks, ed. G.M. Barker, CABI Publishing, New Zeland, pp. 447-488.

Pieri, O. and Jurberg, P. (1981), Aspectos etológicos na sobrevivência dos caramujos vetores da xistosomose ao tratamento com moluscicidas. Mem. Inst. Oswaldo Cruz, 76 (1), 47-55.

Richardot, M. (1977a), Ecological factors inducing estivation in freshwater limpet Ferissia waltieri (Basomatophora, Ancylidae). I. Oxygen content, organic matter content and $\mathrm{pH}$ of the water. Malacol. Rev., 10 (1-2), 159-170.

Richardot, M. (1977b), Ecological factors inducing estivation in freshwater limpet Ferissia waltieri (Basomatophora, Ancylidae). II. Photoperiod, light intesity and water temperature. Malacol. Rev., 10 (12), 113-119.

Stiglingh, I. and Van Eeden J.A. (1977), Population fluctuations and ecology of Bulinus tropicus (Mollusca; Basommatophora). Natuurwetenskappe, 87, 115-127.

Storey, K.B. (2002), Life in slow lane: molecular mechanisms of estivation. Comp. Biochem. Physiol. Part A, 133, 733-754.

Wiktor, A. (1987), Spermatophores in Millacidae and their significance classification (Gastropoda, Pulmonata). Malacologische Abhandlungen, 12 (9), $1-100$.

Received: March 04, 2005; Revised: December 06, 2005; Accepted: September 18, 2006. 